antennæ rapidly diminishing both in length and thickness, the third distinctly shorter than the next two. Length, 2. I mm.

The elytral interspaces are very finely and sparsely punctulate or nearly smooth in blandissima; more evidently punctate in superans. According to Horn, the middle tibia of the male is "normal" in blandissima; in superans the tibia is thickened and arcuately produced internally at apex.

Superans is known only by the unique male type, taken at Tyngsboro, Mass., by Mr. Blanchard.

\title{
ON SOME PREOCCUPIED GENERIC NAMES IN INSECTS.
}

BY G. W. KIRKALDY, HONOLULU, HAWAIAN ISLANDS.

While keeping up to date and partially revising my "Scudder" and "Waterhouse," I have from time to time noted several preoccupied generic names, which, so far as I have been able to find out, have no synonymy whereby the older name could be replaced without fresh creation. As letters to specialists have usually resulted in no action being taken in the matter, I now rename a number of them, in the hope that natural indignation at such an unlawful trespass on my part may induce specialists to purge their own lists. A further number I have left untouched, as I am unable to ascertain their possible synonymy.

\section{Lepidoptera.}

Feredayia, = || Erana, Walker.

Maorides, $=\|$ Exoria, Meyrick.

Americides, $=\|$ Dryope, Chambers.

Pempeltias, $=\|$ Peltophora, Meyrick.

Porina, Walker, is preoccupied, but is probably replaceable by other Walkerian names.

\section{Diptera.}

Neotropicalias, $=\|$ Cyclogaster, Macquart.

\section{Coleoptera.}

Sharpides, $=\|$ Sharpia, Broun.

Nesoptychias, =\| Ptychopterus, Broun.

\section{Hemiptera.}

Philapodemus, = $\|$ Hahnia, Ellenrieder.

Varelia, $=\|$ Munia, Varela. 


\section{$2 \mathrm{BHL}$ Biodiversity Heritage Library}

Kirkaldy, George Willis. 1910. "ON SOME PREOCCUPIED GENERIC NAMES IN INSECTS." The Canadian entomologist 42, 8-8.

https://doi.org/10.4039/ent428-1.

View This Item Online: https://www.biodiversitylibrary.org/item/88727

DOI: https://doi.org/10.4039/ent428-1

Permalink: https://www.biodiversitylibrary.org/partpdf/119052

\section{Holding Institution}

University of Toronto - Gerstein Science Information Centre

\section{Sponsored by}

University of Toronto

\section{Copyright \& Reuse}

Copyright Status: Not provided. Contact Holding Institution to verify copyright status.

This document was created from content at the Biodiversity Heritage Library, the world's largest open access digital library for biodiversity literature and archives. Visit BHL at https://www.biodiversitylibrary.org. 